\author{
Coastal Engineering \\ Manuscript Draft
}

Manuscript Number: CENG-D-08-00132

Title: Beach nourishments at Coolangatta Bay over the period 1987-2005: impacts and lessons

Article Type: Research Paper

Section/Category:

Keywords: Artificial sand bypassing; beach nourishment; dredging; sand supply; embayment

Manuscript Region of Origin:

Abstract: Erosion of the southern Gold Coast beaches (SE Queensland, Australia) was exacerbated after the extension of the Tweed River training walls in the early 1960s. To achieve the objective of restoring and maintaining beach amenity, significant nourishment works have been undertaken in Coolangatta Bay over the past 30 years. Particularly, under the Tweed River Entrance Sand Bypassing Project (TRESBP) since 1995 , a number of nourishment campaigns and the implementation of a permanent sand bypass system in 2001 have resulted in significant changes of Coolangatta Bay morphology. The present case study investigates the influence of both wave climate and nourishment works on the area extending from the updrift Snapper Rocks area to downdrift Kirra Beach. SWAN spectral wave model is implemented at Coolangatta Bay area and forced by the global wave model WW3 to estimate wave forcing and the potential natural longshore drift entering in Coolangatta. Specific transects extracted from accurate bathymetric surveys are used to investigate and quantify Coolangatta Bay sedimentation for the period 1987-2005. A network of Argus video stations provides high sample rate information on the shoreline evolution. Results show that, over the past 10 years, Coolangatta Bay has infilled rapidly. Sedimentation reached up to $6 \mathrm{~m}$ in some areas between 1995 and 2005, with beach width increasing by $200 \mathrm{~m}$ at Kirra Beach. Rapid seaward shoreline migration is consistent with the intense over-pumping of sand relative to the natural potential to move sand alongshore. The nourishment strategy used during this project has successfully delivered large amounts of sand to the southern Gold Coast embayment, although it has been up to now controversial from many community perspectives. The artificial sand bypassing process proved to be much more efficient than depositing the dredged sand in the nearshore area which requires a significant period of low energy condition in order for the deposited sediment to migrate shoreward and weld to the shore. This case study confirms that, when carefully undertaken, sand bypassing is a sustainable and flexible soft engineering approach which can work in concert with natural processes. 



\title{
Beach nourishments at Coolangatta Bay over the period 1987-2005: impacts and lessons
}

\author{
Bruno Castelle ${ }^{1,4}$ Ian L. Turner ${ }^{2}$ Xavier Bertin ${ }^{3}$ \\ Rodger Tomlinson ${ }^{1}$
}

Email address: b.castelle@epoc.u-bordeaux1.fr (Bruno Castelle).

1 Griffith Centre for Coastal Management, Gold Coast Campus, Griffith University,

PMB 50 Gold Coastal Mail Centre, Queensland 9726, Australia

2 Water Research Laboratory, School of Civil and Environmental Engineering, University of New South Wales, NSW 2093, Australia

3 National Civil Engineering Laboratory, Estuaries and Coastal Zones Division, 1700-066, Lisbon, Portugal

4 Université Bordeaux I, CNRS, UMR 5805-EPOC, Avenue des Facultés, Talence, F-33405, France

Preprint submitted to Elsevier

July 30, 2008 


\section{Abstract}

Erosion of the southern Gold Coast beaches (SE Queensland, Australia) was exacerbated after the extension of the Tweed River training walls in the early 1960s. To achieve the objective of restoring and maintaining beach amenity, significant nourishment works have been undertaken in Coolangatta Bay over the past 30 years. Particularly, under the Tweed River Entrance Sand Bypassing Project (TRESBP) since 1995, a number of nourishment campaigns and the implementation of a permanent sand bypass system in 2001 have resulted in significant changes of Coolangatta Bay morphology. The present case study investigates the influence of both wave climate and nourishment works on the area extending from the updrift Snapper Rocks area to downdrift Kirra Beach. SWAN spectral wave model is implemented at Coolangatta Bay area and forced by the global wave model WW3 to estimate wave forcing and the potential natural longshore drift entering in Coolangatta. Specific transects extracted from accurate bathymetric surveys are used to investigate and quantify Coolangatta Bay sedimentation for the period 1987-2005. A network of Argus video stations provides high sample rate information on the shoreline evolution. Results show that, over the past 10 years, Coolangatta Bay has infilled rapidly. Sedimentation reached up to $6 \mathrm{~m}$ in some areas between 1995 and 2005, with beach width increasing by $200 \mathrm{~m}$ at Kirra Beach. Rapid seaward shoreline migration is consistent with the intense over-pumping of sand relative to the natural potential to move sand alongshore. The nourishment strategy used during this project has successfully delivered large amounts of sand to the southern Gold Coast embayment, although it has been up to now controversial from many community perspectives. The artificial sand bypassing process proved to be much more efficient than depositing the dredged sand in the nearshore area which requires a significant period of low energy condition in order for the deposited sediment to migrate shoreward and 
weld to the shore. This case study confirms that, when carefully undertaken, sand bypassing is a sustainable and flexible soft engineering approach which can work in concert with natural processes.

Key words: Artificial sand bypassing, beach nourishment, dredging, sand supply, embayment

\section{$1 \quad 1$ Introduction}

2 Coastal erosion is a worldwide occurrence along sea shores, and has been

3 reported in the literature for several decades. Traditionally, eroding coastlines

${ }_{4}$ have been protected by civil engineering structures involving groynes, seawalls,

${ }_{5}$ breakwaters and the like (Charlier et al., 2005). This approach, while providing

6 local relief, can also result in the transfer of the problem from one geographical

7 site to another. Major advances in the technology of beach nourishment have

8 been made over the past 3 decades (Dean, 1996; Houston, 1991, 1996; Elko

9 et al., 2005). Generally speaking, beach nourishment involves the placement

10 of sediment on an eroding beach to migrate the shoreline seaward in order

11 to promote storm protection, natural habitat and beach amenity. Due to the

12 widespread use of beach nourishment worldwide (Hamm et al., 2002; Hanson

13 et al., 2002), it is now important that not only coastal engineers but also

${ }_{14}$ geoscientists investigating coastal processes understand the performance of

15

16

17

beach nourishments. Various numerical models, both simple (Dean and Yoo, 1992; Elko et al., 2005) and more complex (Van Duin et al., 2004; Li et al., 2006), have been developed to predict the impact of nourishment projects. However, the impact of beach nourishments on both short-term and long-term evolution of complex coastlines warrants continued investigation. 
Coolangatta Bay (Fig. 1), located on the east coast of Australia just north of the state border between Queensland and New South Wales, is a major international and national tourism destination. In the early 60s, the Tweed River entrance training walls, located immediately to the south of Coolangatta Bay (Fig. 2), were extended seaward approximately $380 \mathrm{~m}$ to improve navigation conditions at the entrance. These walls also created a trap for the natural northward longshore drift, resulting in loss of sand supply to the southern Gold Coast beaches (DHL, 1970), particularly in Coolangatta Bay. Coolangatta Bay beaches eroded to an extent that sea walls were constructed to protect property and infrastructure. Coolangatta Bay beaches had not recovered by the early 1990s, despite various groyne constructions and beach nourishment campaigns. These works, culminating in the implementation of a permanent sand bypassing system in 2001, have resulted in significant and complex changes of Coolangatta Bay morphology.

This case study investigates the influence of wave climate, nourishment works and permanent sand bypassing on Coolangatta Bay coastline morphology. The study focuses on the period 1987-2005 which coincides with the implementation of a number of coastal protection measures, and more particularly the period 1995-2005, when the most important changes to the embayment were observed. This work combines accurate bathymetric surveys, video imagery, quantification of beach nourishment and artificial sand bypassing and wave and longshore drift modeling. 


\subsection{Location and settings}

44

The $70 \mathrm{~km}$ long Gold Coast has been the state of Queensland's premier coastal holiday resort destination for more than 40 years. Coolangatta Bay is located at the southern end of the Gold Coast (Fig. 1). The area is characterized by the presence of the Tweed River entrance and a major headland called Point Danger immediately to the south. Figure 2 shows the configuration of Coolangatta Bay including the different coastal structures that have been built over the past few decades: the training walls on both sides of the Tweed River entrance and two groynes (Kirra Point groyne and Miles Street groyne). The area of investigation covers approximately $6 \mathrm{~km}$ of coastline, comprising 3 distinct embayments within Coolangatta Bay: Rainbow Bay, Coolangatta Beach and Kirra Beach. Tides are semi-diurnal, with a tidal range varying from 0.2 to $2 \mathrm{~m}$, with a mean of $1 \mathrm{~m}$. The area is exposed to high energy waves. South to SE waves are generated by intense low pressure systems off the New South Wales coast in winter and spring, and contribute to the main component of the northerly longshore drift. From December to April, tropical cyclones can generate NE to E waves, sometimes with a destructive power (Hobbs and Lawson, 1982), with significant wave height up to $8 \mathrm{~m}$. The sediment consists of fine sand, with $d_{50}=200 \mu \mathrm{m}$. The estimated net rate of littoral sand transport within the general Gold Coast region is of the order of $500000 \mathrm{~m}^{3} / \mathrm{y}$ toward the north (Turner et al., 2006). The Tweed River itself is considered to be a net sink for sediment, as the river discharges minor quantities only of fluvial sand to the littoral system. 
In the early 1960s, the Tweed River entrance training walls were extended seaward approximately $380 \mathrm{~m}$ to improve navigation. The wall extensions improved navigation conditions for almost 20 years before a sand bar moved past the end of the southern training wall to infill the channel once more. The loss of longshore sand supply from the south resulted in the progressive recession of the Coolangatta Bay beaches. The Gold Coast also experienced severe storms in 1967 (McGrath, 1967), 1972 and 1974, resulting in major erosion along the entire SE Australian coastline. As outlined in further details below, a number of measures have been undertaken in an attempt to restore and maintain the southern Gold Coast beaches.

\subsection{Nourishment works}

To achieve the objectives of restoring and maintaining beach amenity, two major nourishment projects were completed to combat beach erosion in Coolangatta Bay over the study period 1987-2005 . The first major nourishment project, called the Southern Gold Coast Beach Nourishment Project, took place between November 1989 and May 1990. This project involved nourishment of the nearshore and upper beach extending from Kirra East to several kilometers north using sand sourced from inactive offshore deposits in water depths of 20 to $28 \mathrm{~m}$. 400,000 $\mathrm{m}^{3}$ of sand was bottom dumped in nearshore areas in water depths of 6 to $9 \mathrm{~m}$, and an upper beach nourishment of 3,200,200 $\mathrm{m}^{3}$ from January to May 1990.

The second phase of nourishment was initiated as a component of the Tweed River Entrance Sand Bypassing Project (TRESBP) commencing in 1995. This project was formulated to overcome the significant erosion of the southern 
Gold Coast beaches as well as to address the navigation issues due to the Tweed River entrance infilling. Stage 1 involved removing the sand bar from the Tweed River entrance to provide material for the initial restoration of the southern Gold Coast beaches. As part of this campaign, $600,000 \mathrm{~m}^{3}$ of sand was placed on the upper beaches from Rainbow Bay in the east to North Kirra in the west. Additional sand quantities were placed in the nearshore (Dyson et al., 2001). Stage 2 resulted from refinements to the Stage 1 placement areas (Boswood et al., 2001; Colleter et al., 2001). An exclusion deposition zone also provided a $100 \mathrm{~m}$ buffer around Kirra natural reef. Most of the sand was placed in an area to the east of Snapper Rock (see deposition areas on Fig. 3). Sand placed in this area was transported by the longshore drift and naturally fed the sandbanks and beaches of the southern Gold Coast. The innovative aspect of the TRESBP (Stage 2) was the implementation in 2001 of a permanent sand bypassing system (see Fig. 2) to collect sand from the southern side of the Tweed River entrance and transport it to the southern Gold Coast beaches in perpetuity (Dyson et al., 2001). The sand was pumped to 5 different locations within Coolangatta Bay (see outlet locations on Fig. 2). The majority of the sand during the period 2001 - 2005 was pumped to the Snapper Rock outlet, at the eastern (updrift) extremity of Coolangatta Bay.

The nourishments during the period 1987 to 2005 are summarized below, with specific location and placement quantities indicated in Tables 1 and 2:

- 1989-1990: Southern Gold Coast Nourishment Project $\left(3,600,000 \mathrm{~m}^{3}\right)$.

- 1995-1996: TRESBP Stage 1A, dredging of Tweed River Entrance and associated nourishment of the southern Gold Coast beaches $\left(2,300,000 \mathrm{~m}^{3}\right)$.

- 1997-1998: TRESBP Stage 1B, dredging of Tweed River Entrance and associated nourishment of the southern Gold Coast beaches $\left(800,000 \mathrm{~m}^{3}\right)$. 
- 2000-2002: TRESBP Stage 2A, dredging of Tweed River Entrance and associated nourishment of the southern Gold Coast beaches $\left(1,100,000 \mathrm{~m}^{3}\right)$.

- 2001: Start of the permanent sand bypassing system

- 2003-2006: TRESBP Stage 2B, dredging of Tweed River Entrance and associated nourishment of the southern Gold Coast beaches $\left(500,700 \mathrm{~m}^{3}\right)$.

\section{Methods and materials}

\subsection{Quantities of delivered sand, potential natural longshore drift and over-} pumping estimation

The spectral wave model SWAN (Booij et al., 1999) is used in stationary mode. The wave forcing provided by the global wave model WW3 (Tolman, 1991) nearest output point (see Fig .1) is applied to the offshore and lateral boundaries of the model. The ability of this modeling strategy to estimate nearshore waves within the Gold Coast region has been successfully demonstrated (Browne et al., 2006, 2007). Accurate bathymetric surveys were used to build a numerical bathymetry with a curvilinear grid at a cell size of $O(100$ $\mathrm{m})$. A more refined rectangular grid (mesh size of $5 \mathrm{~m}$ ) was nested within the coarser curvilinear grid updrift of the Tweed walls on the Leatitia Spit area (Figure 4). Three hour time-series of wave parameters were generated along two representative cross-shore profiles $T 1$ and $T 2$ (Figure 4 ) where the breaking point was defined as the point for which $H_{s} /$ depth $=0.6$. The empirical formula developed by Kaczmarek et al. (2005), using time-series of $H_{s}$ and wave angle to the shore at the breaking point, was used to estimate the corresponding time-series of potential (without training walls) longshore drift 
entering in to the Coolangatta Bay region. Although these sand transport predictions were not directly calibrated with field data, their integration over the study period resulted in values of the order of $500,000 \mathrm{~m}^{3}$, which matches the generally accepted alongshore transport rate for this area (Turner et al., 2006). The same methodology has been successfully applied at a dissipative beach (Bertin et al., 2008) and at a sandspit (Allard et al., 2008) located on the western coast of France. In the following, only the longshore drift computed in $T 1$ is used, as the cross-shore wave parameter profiles at $T 2$ were substantially perturbated by the presence of a shallow shoal (immediately to the Est of T2, see Fig. 4) during SE wave events.

Monthly quantities of delivered sand since the beginning of the permanent sand bypassing system, with associated deposition and pumping locations, were collated from the TRESBP website (www.tweedriverbypass.nsw.gov.au). These monthly sand quantities were used in the present study to assess the impact of dredging and pumping on both the short-term (weekly - monthly) and longer-term (seasonal - multi-year) evolution of Coolangatta Bay morphology. Using computed monthly potential natural sand supply from the downdrift coast and real delivered sand quantities, monthly over-pumping quantities from the TRESBP were estimated.

\subsection{Surveys}

Figure 3 shows the area of interest for the present study, and the period of survey data availability is from $17 / 9 / 1987$ to $15 / 7 / 2005$. Survey data were collected in this area by a number of organizations for a variety of investigations and projects. Not all the surveys have been taken on the same survey lines 
and not all the survey data collected are available for the present study. In the 1970's and 1980's, in response to the severe erosion of Coolangatta Bay, the Gold Coast City Council established survey lines at Coolangatta Beach (CG lines), Kirra Beach (K lines) and Rainbow Bay (RB line). Specific survey lines were chosen to compute the shoreline position. There is an extensive range of shoreline indicators reported in the literature (Boak and Turner, 2005). In the present study, the shoreline position is defined as the intersection of the beach profile with the Mean Sea Level (MSL), which corresponds approximately to 0 m Australian Height Datum (AHD) at the Gold Coast beaches.

The location of the 8 specific survey lines used for this study are shown on Figure 3. The survey lines cover the bay from North Kirra in the west (transect K28) to Rainbow Bay in the east (RB5). These survey lines were chosen because they are representative of the Coolangatta Bay alongshore variations, and importantly, because a large number of surveys were undertaken on these specific transects. At all 8 transct locations, shoreline position has been normalised so that a shoreline position of $0 \mathrm{~m}$ equates to erosion of the beach back to the boulder wall.

\subsection{Video imagery}

Commencing in mid 2002 a network of Argus coastal imaging stations (Holman and Stanley, 2007) has been operating on a continuous basis, providing full coverage of Coolangatta Bay and vicinity. A total of 16 cameras are used, located atop three beach front buildings and a lighthouse, encompassing the southern region of Kirra Beach, Coolangatta Beach, Rainbow Bay/Snapper

Rocks, as well as the up-drift Duranbah Beach located on the southern side of 
Point Danger (refer Fig 2). Two additional and landward-looking cameras are located on the sand bypassing pier, to monitor the localised beach changes in the immediate vicinity of this structure. The cameras were installed for the primary purpose of providing continuous and real-time monitoring capabilities to the TRESBP management team (Turner et al., 2004, 2006). Image analysis is undertaken and updated on a regular (weekly) basis, to document and quantify the longer-term impacts of the bypassing and nourishment operations, and to assess the current beach conditions against a range of target indicators, for the purpose of determining the location and quantity of regular sand delivery (Turner and Anderson, 2007).

The key feature of coastal imaging systems that distinguish them from conventional 'surfcams' is the ability to extract quantitative information from a time-series of digital images. This core capability is achieved through the solution of a set of camera model parameters (Holland et al., 1997), that enable the determination of three-dimensional real-world $[\mathrm{x}, \mathrm{y}, \mathrm{z}]$ position from two-dimensional $[\mathrm{U}, \mathrm{V}]$ image coordinates. These geo-referenced images are then subjected to a range of digital image analysis techniques, to identify, enhance and quantify the particular coastal processes or features of interest. For the present study, the key analysis is determination of the weekly alignment of the shoreline corresponding to mean sea-level. The 'PIC' (Pixel Intensity Clustering) shoreline detection and modeling method is used for this purpose across all Coolangatta Bay sites (Aarninkhof et al., 2003; Plant et al., 2007). Weekly beach widths are then extracted from the time-series of shorelines, corresponding to the same 8 locations for each of the longer-term (pre 2002) but less frequent survey transects, identified in the previous section. 


\subsection{Pre-TRESBP Coolangatta Bay evolution}

Figure 5 shows the temporal morphological variability of the 8 specific crosshore transects gathered from the bathymetric surveys throughout the study period. In particular, it shows that there is no significant bathymetric change deeper than $15 \mathrm{~m}$ depth. Difference in beach profile sometimes reached $8 \mathrm{~m}$ showing the strong variabilities of both the bay morphology and shoreline positions over the study period. Figure 6 shows the time-series of the shoreline evolution between 1987 and 2005 for these 8 crosshore transects. This figure shows that, prior to the Southern Gold Coast Nourishment Project in 1989, the shoreline positions were experiencing a generally slow decreasing trend. This progressive erosion was resulting from the re-establishing of sand transport pathways at the Tweed Entrance. In the late 80s, both the spit southward (updrift) of the Tweed River training walls and the Tweed bar were approaching a new equilibrium, and the Tweed River was also approaching the pre-1962 situation. Thus, natural sand bypassing had greatly increased resulting in a weaker rate of shoreline retreat that was experienced in the 1960's and 1970's (DHL, 1992). However, Coolangatta Bay and particularly Kirra, was still at this time the top Gold Coast nourishment priority and the beach zone identified as in most need of storm protection (Smith and Jackson, 1993).

The 1989 beach nourishment was quite unique as compared with previous Gold Coast nourishment works. To satisfy community demand, it was chosen to place only $11 \%$ of the total amount of sand in the nearshore area, with the bulk of the sand placed at the beachface in order to create an 'instant' and 
visibly wider beach. The onshore nourishment (89\%) substantially offset the erosion of the beaches from Kirra to a few kilometers to the North, though the nourishment volume had not fully offset the severe erosion at Kirra and the eastern beaches of Coolangatta Bay (DHL, 1992). This beach response is obvious on Fig. 6: the western part of Coolangatta Bay (transects K1, K9, K17 and K28) experienced a seaward shoreline migration of $120 \mathrm{~m}$ on average, while the eastern part (PSM18, CG9, CG6 and RB5) experienced a very weak accretive event. During the period 1990-1995, the beach width remained relatively stable, with a $50 \mathrm{~m}$ shoreline retreat on average westward to Kirra groyne.

In 1995, Stage 1A of the TRESBP resulted in a marked beach width increase in the whole bay. This was particularly evident for Coolangatta Beach and the eastern part of Kirra Beach. A 40 m reduction in the ledgth of the Kirra Point groyne was also implemented at this same time. The most significant evolution of Coolangatta Bay is observed from 2001, which coincided with the start of the permanent sand bypassing. This period 1995-2005 is described in more details below.

\subsection{Annual morphological evolution of Coolangatta Bay 1995-2005 (TRESBP)}

Figure 7 shows the evolution of the computed Coolangatta Bay morphology during the TRESBP, and reveals significant changes of the sub-aerial beach. Rainbow Bay beach experienced the least significant changes over the study period, while Coolangatta beach and particularly Kirra beach intensively evolved. Vertical accretion reached $6 \mathrm{~m}$ over the period in some areas of Kirra beach and Miles Street groyne was mostly buried by sand in 2005 . 
The water line reached Kirra Point groyne only at high tide. In 2005, both Coolangatta and Kirra beach were about $200 \mathrm{~m}$ wide with non-vegetated dunes reaching $6 \mathrm{~m}$ above AHD. In contrast, since 2002, Rainbow beach has experienced a weak erosive state, Coolangatta Beach appears to have reached a quasi-equilibrium state and Kirra beach continued to infill rapidly.

The nearshore area also experienced intense changes. Referring to Figure 7, before 2001, the nearshore bar was mirroring the shape of the crenulated embayments, but this feature has now both widened and straightened. This straight nearshore bar development started in 2001 and coincided with the start of the permanent sand bypassing. The nearshore bar changed its orientation westward to Kirra groyne between 2002 and 2005. This change in the nearshore bar configuration was associated with an intense beach width growth of Kirra Beach.

Figure 8 shows the time-series of the shoreline position for each of the 8 beach profiles, together with offshore wave conditions and the monthly volume (including placement areas) of both pumped and deposited sand in the bay. This figure clearly shows the coincidnence of significant evolution of Coolangatta Bay and the implementation of the TRESBP, as expected, given that there has been significant over-pumping of sand relative to the natural potential to move sand alongshore (Tables 1 and 2). Indeed, offshore wave conditions during this five year monitoring period do not appear to have had a significant impact on the global evolution of the bay, as this interval coincided with a relatively calm period for the Gold Coast beaches, with no severe erosive event(s) observed.

Both Stage 1A and Stage 1B dredging had a significant impact on the shore- 
line position of the eastern part of Coolangatta Bay. The western part of Coolangatta Bay did not experience significant change of the shoreline position over the period prior to the artificial sand bypassing plant implementation (Fig. 7 and 8). The start of the artificial sand bypassing resulted in an almost immediate seaward migration of the shoreline in the whole bay (except the eastern extremity: K17 and K28). At the beginning (early 2001), increasing beach width was observed at the eastern extremity of Coolangatta Bay i.e. Rainbow Bay (RB5 on Fig. 4). In late 2001, beach width increased at Coolangatta Beach (CG6 and CG9), then at Kirra in 2002. Since 2002, the shoreline position in the eastern part of Coolangatta Bay (RB5, CG9, CG6) was almost stable, with a slight downward trend, while Kirra continues to infill from the east to the west.

\subsection{Short-term (weekly) shoreline evolution in response to over-pumping}

Figure 9 shows time-series of both monthly over-pumped quantities of sand relative to the natural potential to move sand alongshore and weekly shoreline position computed from the video imagery. This figure reveals the impact of over-pumping on the shoreline position within the bay on the time scale of days to months which was impossible to grasp from the previous (annual) beach survey analysis.

These monitoring data show that over- or under-pumping has an almost immediate impact in Rainbow Bay (transect RB5). For instance, it only takes a few days for the RB5 shoreline position to migrate seaward when substantial over-pumping occured. As soon as under-pumping or weak over-pumping occurs, the RB5 shoreline position migrated shoreward. When the delivered 
sand quantities remain close to the potential natural longshore drift for a few months, for instance early 2005 (Fig. 9), the RB5 shoreline position seems to oscillate around and equilibrium position at about $50 \mathrm{~m}$. The impact of overpumping on Coolangatta Beach can also be noticed for the transect CG6. A substantial lag exists between the over-pumping peaks and the CG6 shoreline evolution (Fig. 8). Most of the peaks can be identified on Fig. 8, with a lag estimated to be of about 5 to 6 month. Given the CG6 and RB5 transects are about $500 \mathrm{~m}$ spaced, the bulk of sand migration rate can be estimated to be on the order of $100 \mathrm{~m} /$ month between Rainbow Bay and Coolangatta Beach. The impact on the CG9 shoreline position is barely shown on Fig. 8 as the Kirra Point groyne (Fig. 2) acts as a sand trap and tends to filter the sand bulk migration. This sand bulk migration is much more difficult to identify within the Kirra Beach embayment. The overall observed trend is characterized by a quasi-steady seaward migration of the shoreline from Kirra Point groyne to the K17 transect, as observed from the beach survey analysis (Fig. 7). This behaviour shows once again that Kirra Beach seems to act as a sediment sink and keeps infilling to a significant degree.

\section{Discussion and conclusions}

\subsection{Site specific outcomes}

Coolangatta Bay experienced significant morphological changes over the past decade, extending from $15 \mathrm{~m}$ water depth landward to the subaerial beach. Vertical accretion has reached $6 \mathrm{~m}$ in some areas such as Kirra Beach, where the seaward shoreline migration attained $200 \mathrm{~m}$. In comparison to the de- 
pleated beach conditions in the 1980s, it is evident that the TRESPB has been successful in both increasing the beach width and enhancing the ability of the southern Gold Coast beaches to accomadate future extreme events. From a local perspective, the principal outcomes of the present study are:

(1) The Coolangatta Bay beaches are very wide. The shoreline seaward migration ranged from $50 \mathrm{~m}$ in Rainbow Bay to more than $200 \mathrm{~m}$ at Kirra Beach in comparison to the shoreline prior to the TRESBP. The subaerial beach is currently a significant buffer against a severe storm event. The beaches of Kirra and Coolangatta seem to be currently the most able to withstand extreme event of all the Gold Coast beaches (Castelle et al., 2008).

(2) Kirra Beach appears to act as a downdrift sink. This is not surprising given that this section of coastline experienced the greatest negative impact of the erosion wave that followed the construction of the Tweed walls.

(3) Rapid evolution (weekly to monthly) seems to be strongly correlated to the over-pumping of sand relative to the natural potential to move sand alongshore. The resulting bulk of sand observed from Snapper Rocks to Kirra Point groyne migrates toward the Kirra section at a rate of the order of 100 $\mathrm{m} /$ month. The bulk of sand is then trapped in the Kirra Beach embayment.

In 2005, the TRESBP had been successful in providing wide and healthy beaches within Coolangatta Bay. However, worldwide no beach nourishment or coastal engineering works program will ever meet everybody's expectiations. The TRESBP is another example, as several issues have been raised recently by the community, despite the overall success of the engineering components of the project. Some locals and tourists opinions are that beaches are currently too wide (especially at Kirra), and that surfing, swimming, fishing, diving 
and beach use amenity has been compromised as a result of over-pumping.

The width of the nearshore bar has increased such that the natural rock reef seaward of Kirra Beach (Fig. 1) is threatened to be fully covered by sand, which raises both fishing and ecological integrity issues. The formation of the straight and wide nearshore bar along the whole bay, known by the surfers as "Superbank", is regarded by some to have resulted in the disappearance of Kirra Point's world-class surf break.

\subsection{Generic lessons learnt}

This case study at Coolangatta Bay demonstrates that artificial sand bypassing can have a significant and rapid impact on beach and nearshore morphology. Sand that is pumped to shallow water is readily transported by the longshore current and can naturally feeds the sandbanks and beaches. This process has proven to be much more efficient than depositing the dredged sand in the nearshore area, which requires a significant period of low energy conditions in order for the deposited sediment to migrate shoreward and weld to the shore.

Several arguments support the use of sand bypassing system in coastal areas where significant net longshore drift is observed, and where this sand supply has been interrupted. Indeed, nourishment works often result from the desire to both dispose of available sand dredged to maintain navigable depths in a nearby harbor or inlet, and widen the beach (for storm damage-reduction purposes and/or recreational space). Permanent sand bypassing systems can potentially offer the possibility to both remediate these issues and later prevent them in a sustainable way. If properly formulated and managed, this strategy 
can remove the requirement for regular refills, dredging and additional hard structures. Collecting sand at the updrift coast also means that the same grain size as the native one is deposited, which is a generally favoured. As illustrated in this case study, behavior oriented numerical models can be used to estimate potential natural longshore drift along sandy coastlines. Therefore, it is possible to pump sand quantities comparable to the natural longshore drift. This can allow permanent sand bypassing systems to work in concert with natural processes. These possible dynamic and flexible characteristics of the implementation of permanent sand bypassing system may have to be taken into greater account in future practices.

It must also be recognised that sand bypassing may be ineffective or inappropriate, dependant upon site specific considerations. For example, overpumping can have negative consequences on natural habitats. In the case of Coolangatta Bay, a large amount of natural reefs were buried under tons of sand, which raised both fishing and ecological integrity issues. Coarser sand than the native beach material is sometimes preferably used in beach fill practices, particularly when there is requirement for offsetting serious erosion and stabilizing the upper part of the beach. This cannot be achieved with sand bypassing alone.

Hamm et al. (2002) strongly recommended the development of monitoring strategy and techniques together with sustainable soft engineering approach. Use of innovative techniques such as video-imaging, accurate bathymetric surveys, and the properly documented quantities of delivered sand quantities, offer a great potential for obtaining very valuable operational and long-term monitoring data at Coolangatta Bay and other coastal management sites world-wide. 
Acknowledgements:

The research presented in this paper was performed within the framework of the development of a Gold Coast Shoreline Management Plan (GCSMP) on behalf of the Gold Coast City Council (GCCC). Xavier Bertin was funded by the European Commission through a Marie Curie Intra-European Fellowship (contract IMMATIE MEIF-CT-2006-041171). The authors wish to acknowledge the permission of the Tweed River Entrance Sand Bypassing Project (TRESBP), NSW Department of Lands and Queensland Environmental Protection Agency (QEPA). The authors wish to thank GCCC for providing some of the field surveys and Debbie Abbs for providing the WW3 forcing for the study period. Funding to UNSW to operate the ARGUS stations is jointly provided by the NSW and QLD state governments.

\section{References}

Aarninkhof, S. G. J., Turner, I. L., Dronkers, T. D. T., Caljouw, M., Nipius, L., 2003. A video-based technique for mapping intertidal beach bathymetry. Coastal Engineering 49 (4), 275-289.

Allard, J., Bertin, X., Chaumillon, E., Pouget, F., 2008. Sandspit rhythmic progradation: a potential record of wave climate variation? The Arçay Sandspit, Western Coast of France. Marine Geology 253, 107-131.

Bertin, X., Castelle, B., Chaumillon, E., Butel, R., Quique, R., 2008. Longshore drift estimation and inter-annual variability at a high-energy dissipative beach: St. Trojan Beach, SW Oléron Island, France. Continental Shelf Research 28, 1316-1332.

Boak, E. H., Turner, I. L., 2005. Shoreline definition and detection: A review. Journal of Coastal Research 21 (4), 688-703. 
Booij, N., Ris, R. C., Holthuijsen, L. H., 1999. A third-generation wave model for coastal regions, Part I: Model description and validation. Journal of Geophysical Research 104 (C4), 7649-7666.

Boswood, P., Victory, S., Lawson, S., 2001. Placement strategy and monitoring of the Tweed River Entrance Sand Bypassing Project nourishment work. In: Proc. Coasts and Ports Conference 2001. pp. 253-258.

Browne, M., Castelle, B., Strauss, D., Tomlinson, R. B., Blumenstein, M., Lane, C., 2007. Estimating onshore break size from a global wind-wave model: an empirical approach using artificial neural networks. Coast. Eng. $54(5), 445-460$.

Browne, M., Strauss, D., Castelle, B., Blumenstein, M., Tomlinson, R. B., Lane, C., 2006. Empirical estimation of nearshore waves from a global deepwater wave model. IEEE Geoscience and Remote Sensing Letters 3 (4).

Castelle, B., Le Corre, Y., Tomlinson, R. B., 2008. Can the Gold Coast beaches withstand extreme events? Geo-Marine Letters 28, 23-30.

Charlier, R. H., Chaineux, M. C. P., Morcos, S., 2005. Panorama of the history of coastal protection. Journal of Coastal Research 21 (1), 79-111.

Colleter, G., Cummings, P., Aguilar, P., Walters, R., Boswood, P., 2001. Monitoring of Tweed River Entrance dredging and nourishment activities. In: Proc. Coasts and Ports Conference 2001. pp. 259-264.

Dean, R. G., 1996. Beach nourishment performance: planform consideration. Shore and Beach 64 (3), 36-39.

Dean, R. G., Yoo, C. H., 1992. Beach nourishment performance predictions. Journal of Waterway, Port, Coastal and Ocean Engineering 118 (6), 567586.

DHL, 1970. Gold Coast, Queensland Australia - Coastal erosion and relative problems. Tech. Rep. R257, Delft Hydraulics Laboratory, The Netherlands. 
DHL, 1992. Southern Gold Coast littoral sand supply. Tech. Rep. H85, Delft Hydraulics Laboratory, The Netherlands.

Dyson, A., Victory, S., Connor, T., 2001. Sand bypassing the Tweed River Entrance: an overview. In: Proc. Coasts and Ports Conference 2001. pp. $310-315$.

Elko, N. A., Holman, R. A., Gelfenbaum, G., 2005. Quantifying the rapid evolution of a nourishment project with video imagery. Journal of Coastal Research 21 (4), 633-645.

Hamm, L., Capobianco, M., Dette, H. H., Lechuga, A., Spanhoff, R., Stive, M. J. F., 2002. A summary of European experience with shore nourishment. Coastal Engineering 47, 237-264.

Hanson, H., Brampton, A., Capobianco, M., Dette, H. H., Hamm, L., Laustrup, C., Lechuga, A., Spanhoff, R., 2002. Beach nourishment projects, pratices, and objectives - a European overview. Coastal Engineering 47, 81-111.

Hobbs, J. E., Lawson, S. W., 1982. The tropical cyclone threat to the Queensland Gold Coast. Applied Geography 2, 207-219.

Holland, K. T., Holman, R. A., Lippman, T. C., Stanley, J., Plant, N. G., 1997. Practical use of video imagery in nearshore oceanographic field studies. IEEE Journal of Oceanic Engineering 22 (1), 81-92.

Holman, R. A., Stanley, J., 2007. The history and technical capabilities of ARGUS. Coastal Engineering 54 (6-7), 477-491.

Houston, J. R., 1991. Beachfill performance. Shore an Beach 59 (3), 15-24.

Houston, J. R., 1996. Engineering practice for beach-fill design. Shore and Beach 64 (3), 27-35.

Kaczmarek, J. M., Ostrowski, R., Pruszak, Z., Rozynski, G., 2005. Selected problems of sediment transport and morphodynamics of a multi-bar nearshore zone. Estuarine, Coastal and Shelf Science 62, 415-425. 
Li, F., Dyt, C., Griffiths, C., 2006. Multigrain sedimentation/erosion model based on cross-shore equilibrium sediment distribution: application to nourishment design. Estuarine, Coastal and Shelf Science 67, 664-672.

McGrath, B. L., 1967. Erosion of Gold Coast beaches. J. Int. Eng. Aust. 40, $155-166$.

Plant, N. G., Aarninkhof, S. G. J., Turner, I. L., Kingston, K., 2007. The performance of shoreline detection models applied to video imagery. Journal of Coastal Research 23 (3), 658-670.

Smith, A. W. S., Jackson, L. A., 1993. A review of Gold Coast nourishment 1972-1992. Tech. Rep. 181, Gold Coast City Council, Australia.

Tolman, H. L., 1991. A third-generation model for wind waves on slowly varying, unsteady and inhomogeneous depths and currents. Journal of Physical Oceanography 21, 782-797.

Turner, I. L., Aarninkhof, S. G. J., Holman, R. A., 2006. Coastal imaging applications and research in Australia. Journal of Coastal Research 22 (1), $37-48$.

Turner, I. L., Aarninkhof, S. J. D., Dronkers, T. D. T., MacGrath, J., 2004. GZM applications of ARGUS Coastal Imaging at the Gold Coast, Australie. Journal of Coastal Research 20 (3), 947-971.

Turner, I. L., Anderson, D. J., 2007. Web-based and 'real-time' beach management system. Coastal Engineering 54, 555-565.

Van Duin, M. J. P., Wiersma, N. R., Walstra, D. J. R., Van Rijn, L. C., Stive, M. J. F., 2004. Nourishing the shoreface: observations and hindcasting of the Egmond case, The Netherlands. Coastal Engineering 51, 813-837. 


\section{Table captions}

Table 1. Dredging quantities $\left(\mathrm{m}^{3}\right)$ and placement area over the period 19952005

Table 2. Pumping quantities $\left(\mathrm{m}^{3}\right)$ and outlet locations over the period 20012005 


\begin{tabular}{|c|c|c|c|c|}
\hline Year & D1 & D2 & D3 & Total \\
\hline 1995 & $?$ & $?$ & $?$ & 1731949 \\
\hline 1996 & $?$ & $?$ & $?$ & 572403 \\
\hline $1997 / 1998$ & $?$ & $?$ & $?$ & 800407 \\
\hline 2000 & 237266 & 73010 & 96007 & 405853 \\
\hline 2001 & 9721 & 257996 & 148490 & 416207 \\
\hline 2002 & 190285 & 9014 & 40831 & 240130 \\
\hline 2003 & 146628 & 57425 & 26839 & 230892 \\
\hline 2004 & 123771 & 11200 & 34955 & 169926 \\
\hline 2005 & 111483 & 38573 & 26133 & 176189 \\
\hline
\end{tabular}

Table 1

\begin{tabular}{|l|l|l|l|l|l|l|}
\hline Year & OSRE & OSRW & OK & OD & OG & Total \\
\hline 2001 & 409746 & 1586 & 97279 & 67258 & 0 & 575869 \\
\hline 2002 & 564577 & 0 & 84915 & 71872 & 0 & 721364 \\
\hline 2003 & 602953 & 0 & 81918 & 70224 & 31931 & 787026 \\
\hline 2004 & 459554 & 0 & 0 & 36813 & 0 & 496367 \\
\hline 2005 & 683244 & 0 & 0 & 41687 & 0 & 724931 \\
\hline
\end{tabular}

Table 2 


\section{Figure captions}

Figure 1. Location of Coolangatta Bay (Queensland, Australia) with indication of the WW3 grid point and the SWAN grid boundary used for wave modeling

Figure 2. Aerial photograph of Coolangatta Bay (July 1998) with general settings and superimposed permanent sand bypassing system layout

Figure 3. Coolangatta Bay morphology (October 2004) with locations of the specific survey transect lines, video imagery transect lines, the SWAN wave output point and the 3 main deposition areas D1, D2 and D3 (KB=Kirra Beach, $\mathrm{CGB}=$ Coolangatta Beach, $\mathrm{RBB}=$ Rainbow Bay Beach)

Figure 4. Evolution of Coolangatta Bay from 1997 to 2005: beach widening and formation of a straight and wide nearshore bar. The thick dot line is the shoreline location (0 AHD) and the thick line is the spring high tide sea level

Figure 5. Superimposed beach profiles over the period 1987-2005 for the specific survey lines, with indication of the Lowest Astronomical Tide (LAT) level, Mean Sea Level (MSL) and Highest Astronomical Tide (HAT) level

Figure 6. Shoreline evolution at the specific survey lines over the period 1987-2005

Figure 7. Evolution of Coolangatta Bay from 1997 to 2005: beach widening and formation of a straight and wide nearshore bar. The thick dot line is the shoreline location (0 AHD) and the thick line is the spring high tide sea level

Figure 8. Time-series of significant wave height $H_{s}$ in the Bay with superim- 
posed 15 days low-pass-filtered $H_{s}$ (thick line), pumping and dredging quantities, and shoreline position at the specific transects over the period 1995-2005. OSRE: Snapper Rock East Outlet; OSRW: Snapper Rock East Outlet; OK: Kirra Outlet; OD: Duranbah Outlet; OG: Greenmount Outlet

Figure 9. Time-series of over-pumping quantities and shoreline positions using video imagery during the TRESBP 


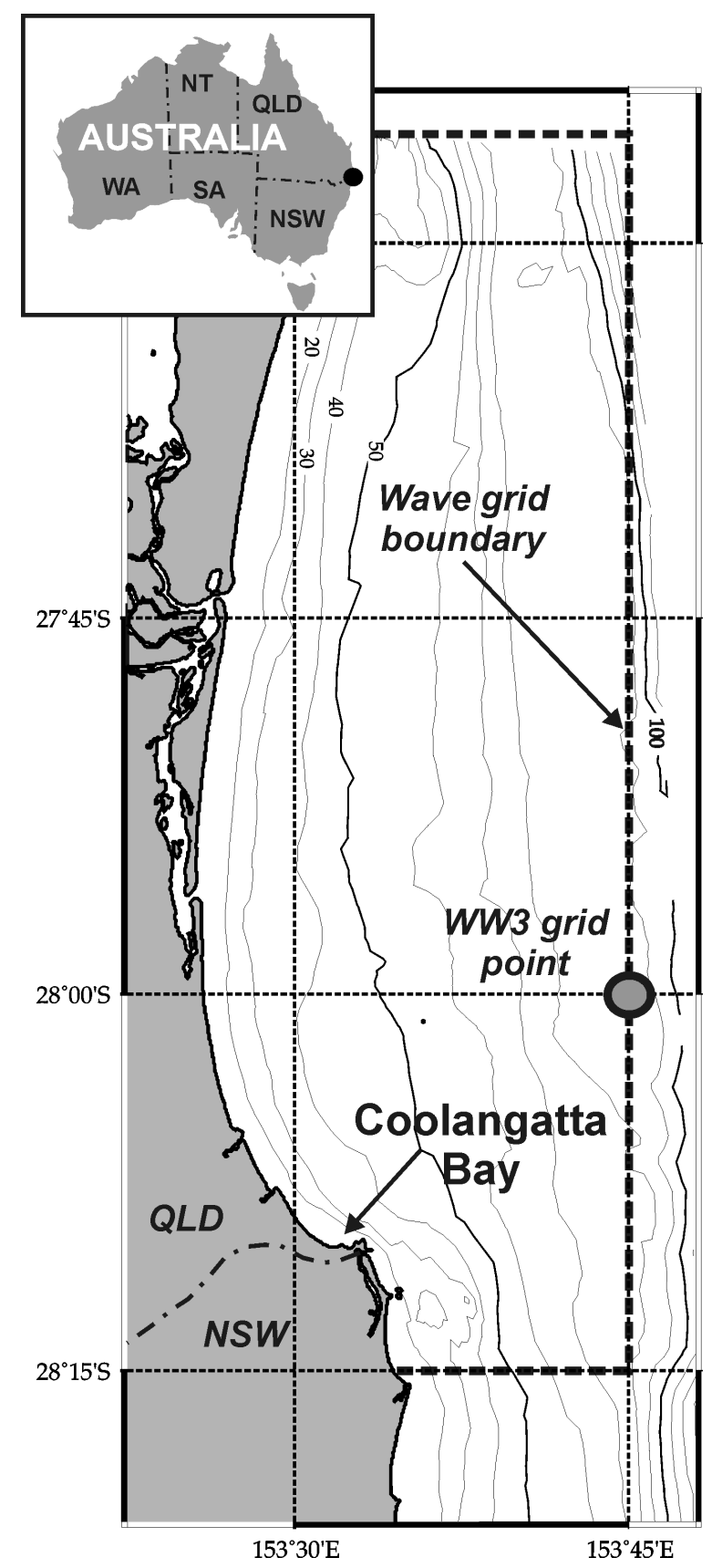

Figure 1. 


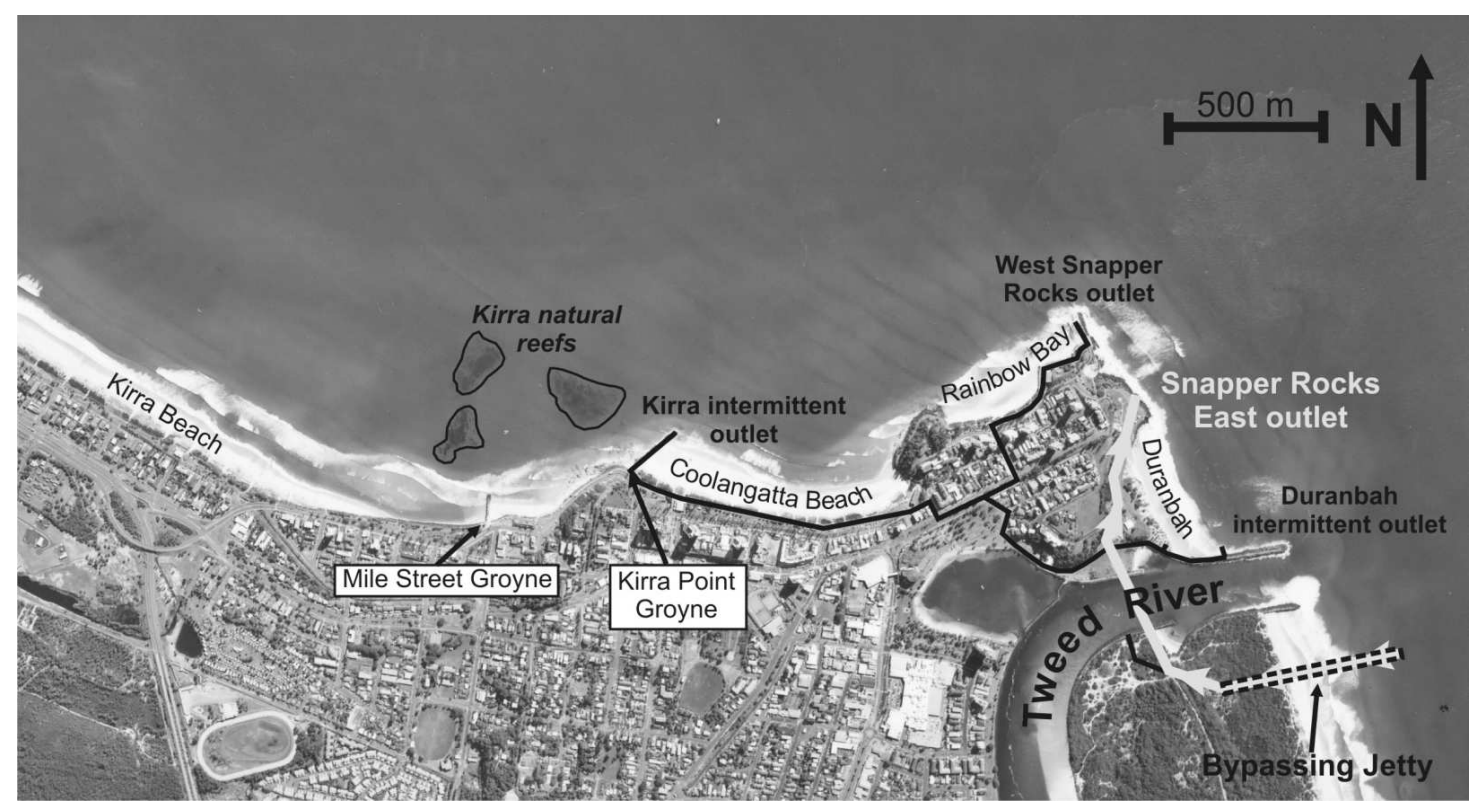

Figure 2.

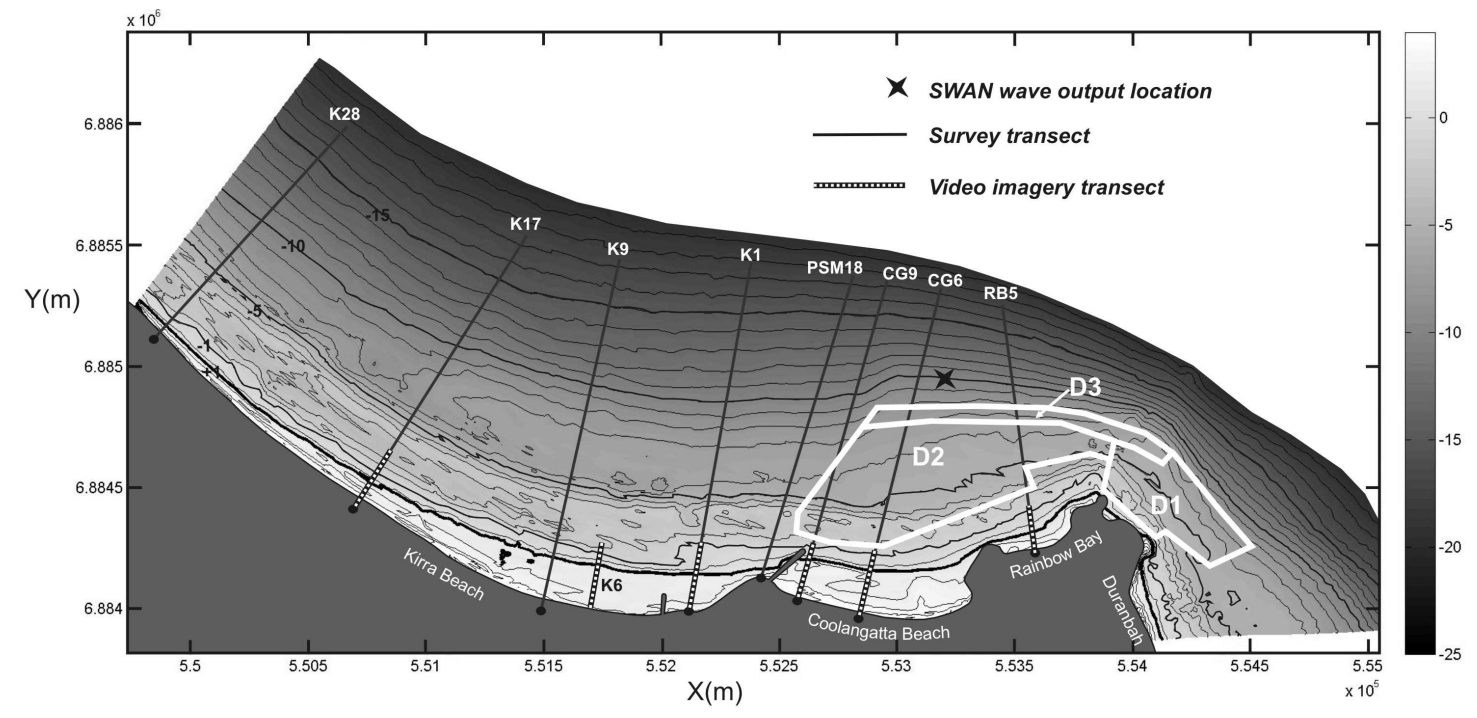

Figure 3. 


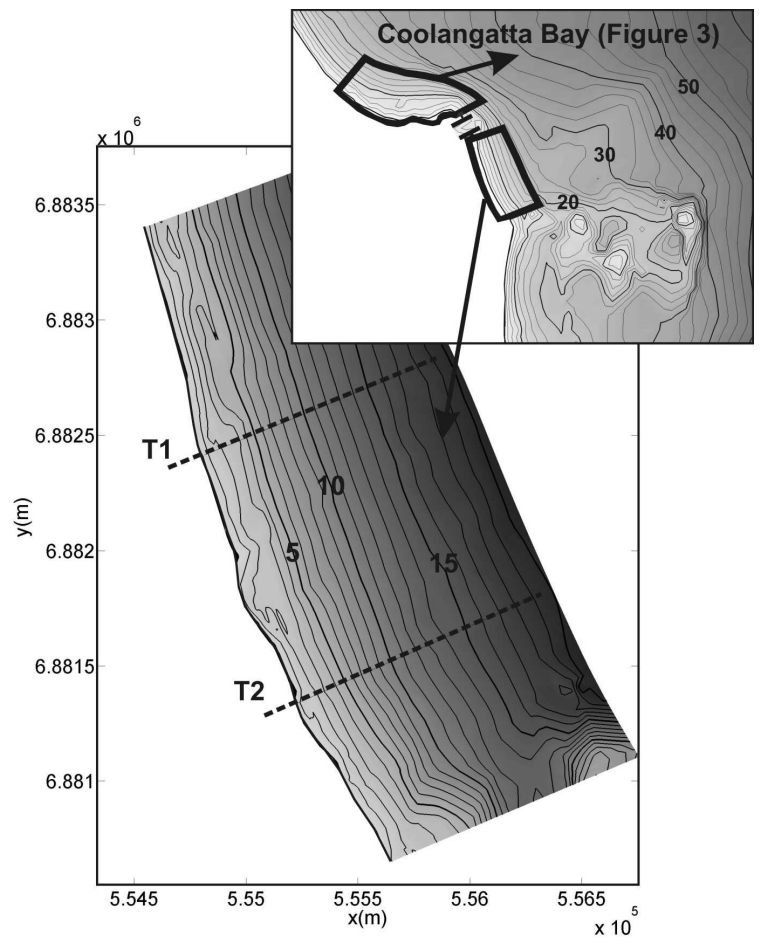

Figure 4 . 

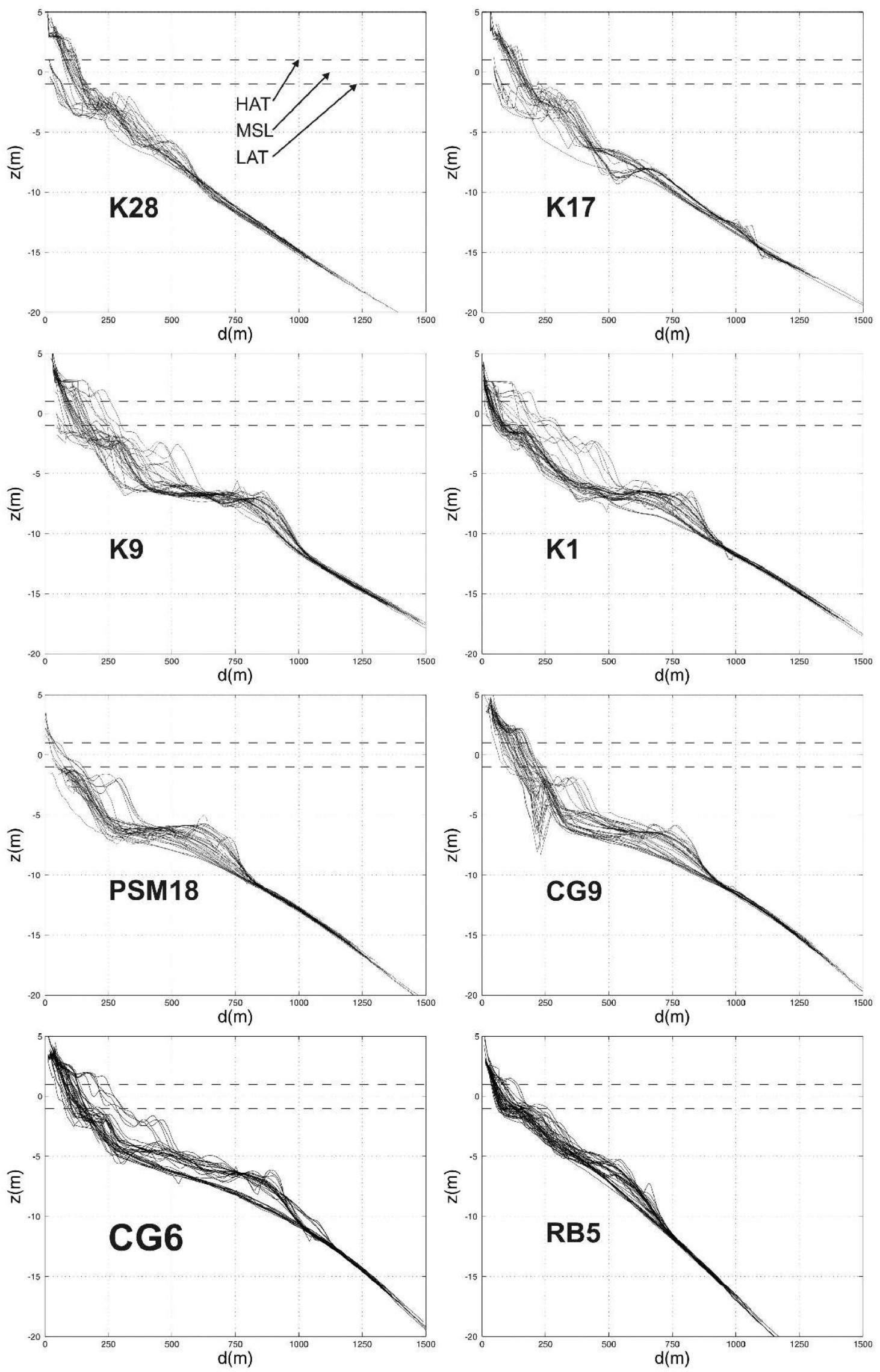

Figgie 5. 

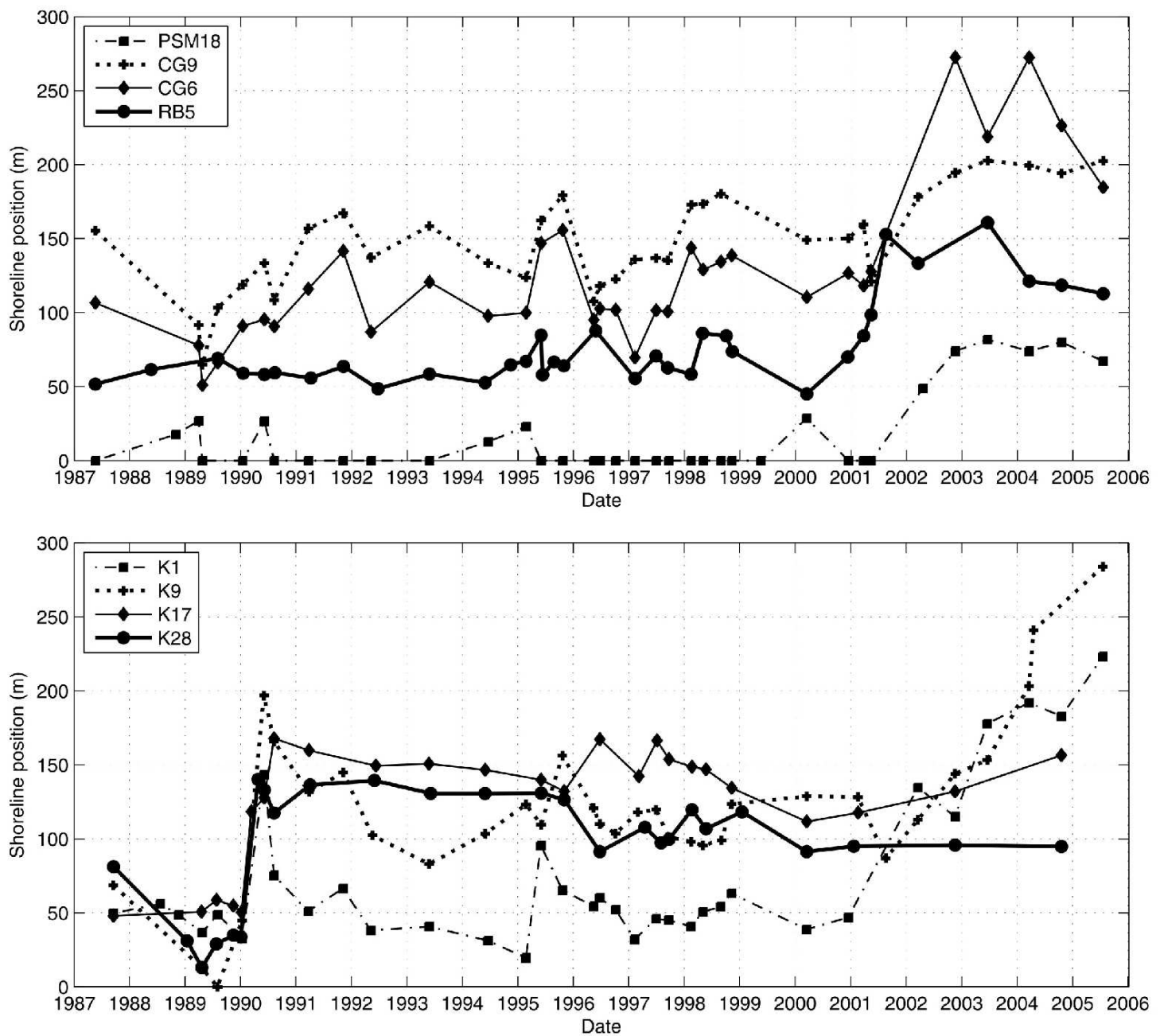

Figure 6. 

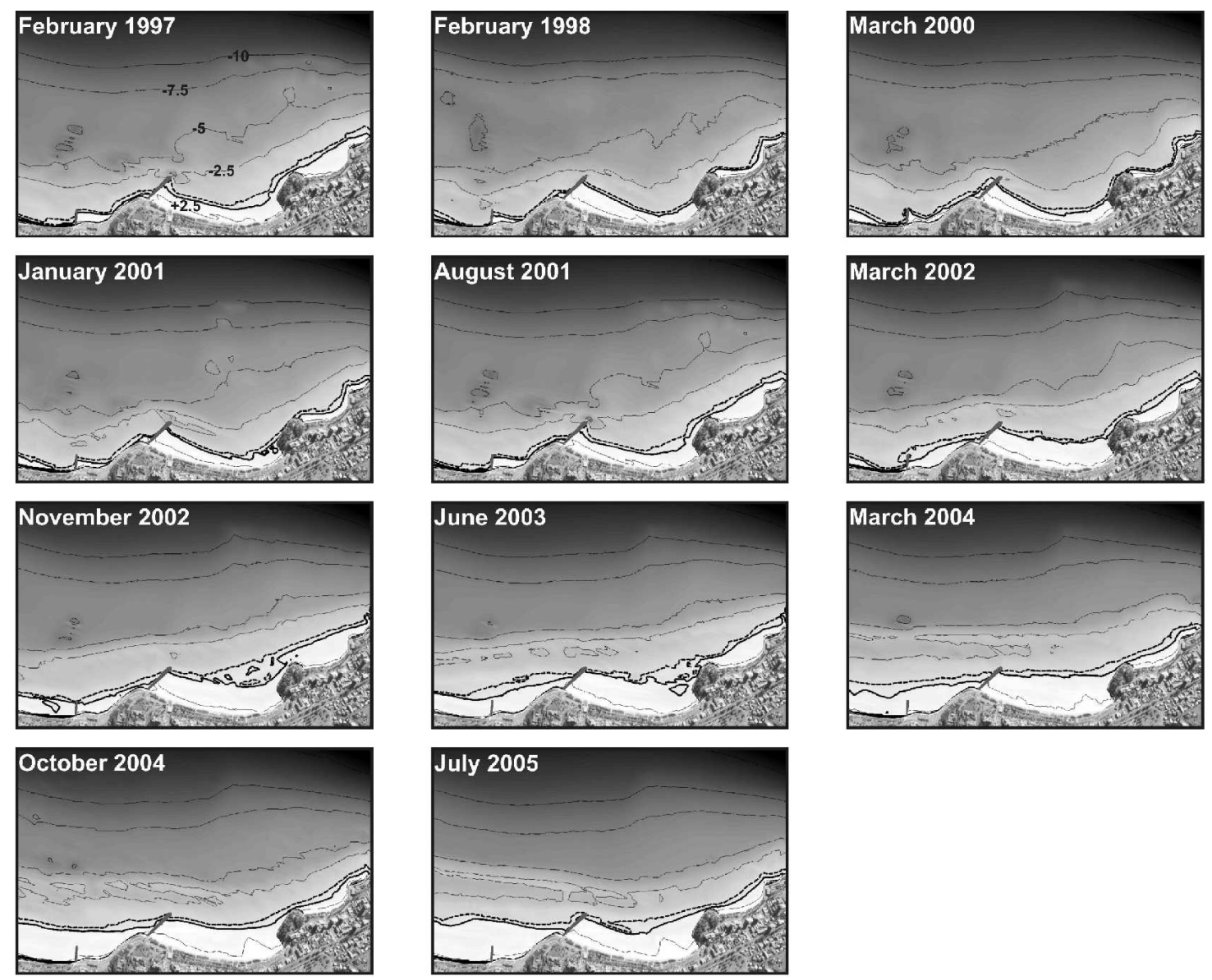

Figure 7. 

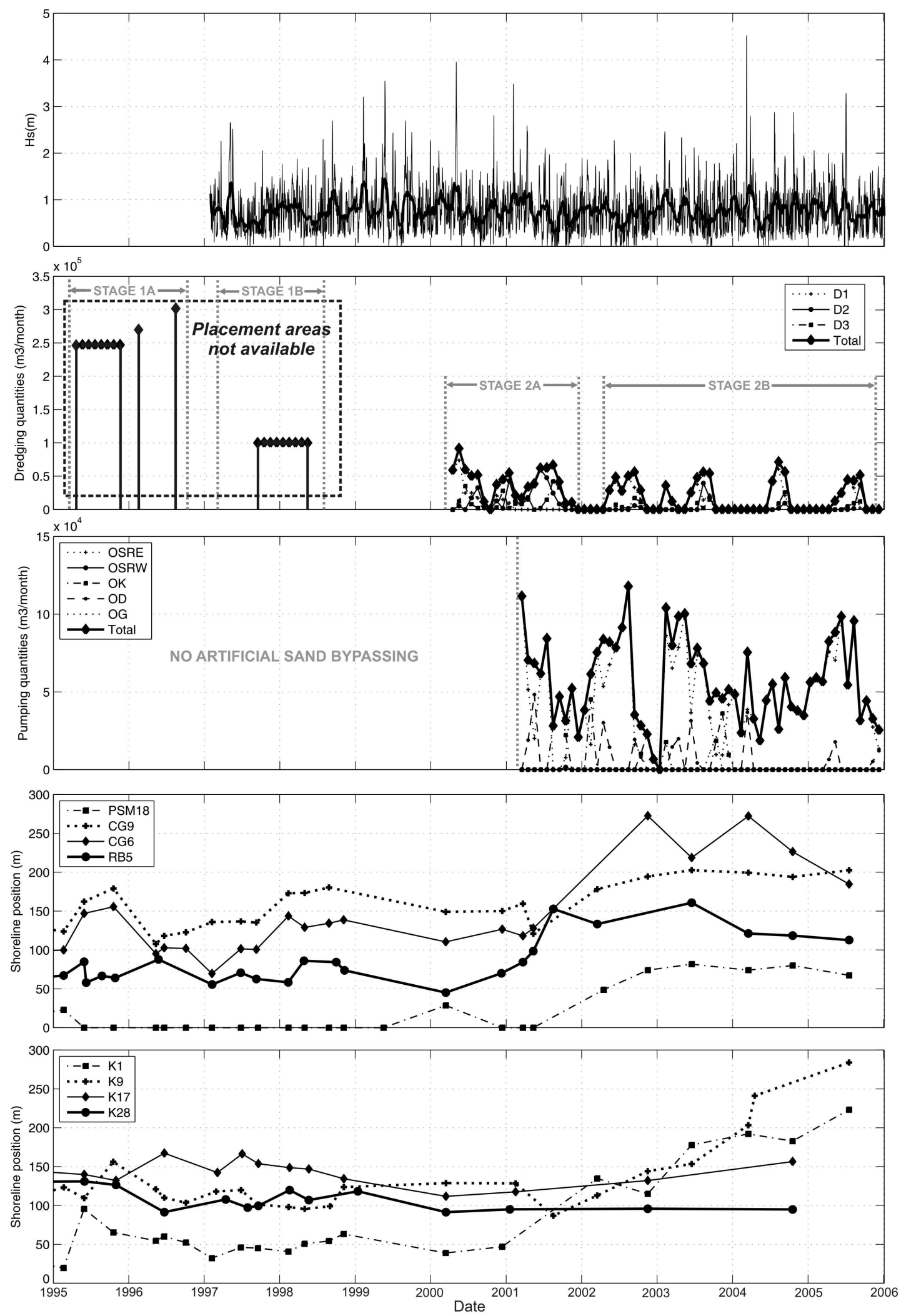

Figure 8. 

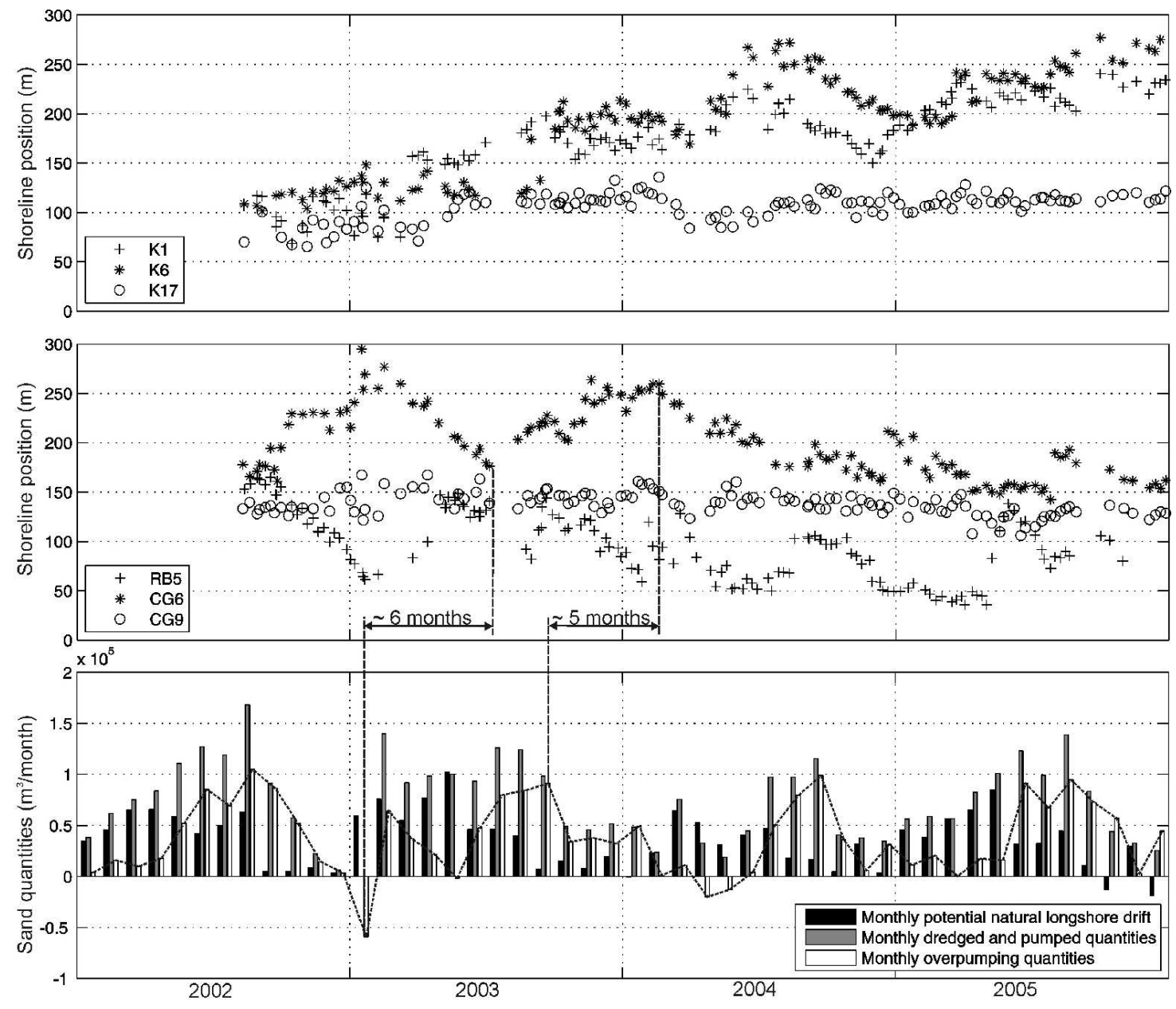

Figure 9. 